\title{
CONCEITO DE CATARSE PARA VIGOTSKI E A DIMENSÃO SENSÍVEL DO CINEMA: UM DIÁLOGO ENTRE A SÉTIMA ARTE E A PSICOLOGIA HISTÓRICO CULTURAL
}

\author{
Amanda de Melo Omodei ${ }^{i}$ 0000-0003-3414-5323 \\ Universidade Estadual de Maringá - UEM \\ Alvaro Marcel Palomo Alvesii ${ }^{\mathrm{ii}}$ 0000-0002-8320-3131 \\ Universidade Estadual de Maringá - UEM
}

\begin{abstract}
RESUMO: Esta pesquisa opera a partir da teoria proposta por Vigotski e reflete como conceito de catarse pode ser uma ferramenta produtora de subjetividade quando em associação com o cinema. A pesquisa constitui-se à luz da psicologia sócio-histórica e adota o materialismo históricodialético como método. Para Vigotski o humano é um ser social e a cultura deve ser interpretada como a matéria-prima do desenvolvimento do psiquismo. É ela que nos fornece aparato e elementos simbólicos que permitem a representação da realidade. Assim, a pesquisa buscou selecionar núcleos de significação que pudessem sustentar a discussão a respeito da catarse enquanto um processo. Foi realizada a
\end{abstract}

técnica de grupo focal tendo como instrumento principal o filme "Relatos Selvagens" do argentino Daminán Szifron, destacando-se dois núcleos de significação: emoção e moral. $\mathrm{O}$ primeiro núcleo - emoção- foi discutido a partir da concepção vigotskiana de emoções e vivências; já o entendimento de moral como um segundo núcleo permitiu um diálogo com a visão materialista da moral de Sánchez Vázquez. Por conseguinte, sendo o indivíduo um ser que se desenvolve a partir da mediação, o cinema pode ser considerado um instrumento de transmissão cultural, atuando concomitantemente com a catarse na transformação sensível do indivíduo.

PALAVRAS-CHAVE: Psicologia da arte. L. S. Vigotski. Cinema

\section{CATARSE CONCEPT FOR VIGOTSKI AND THE SENSITIVE DIMENSION OF CINEMA: A DIALOGUE BETWEEN THE SEVENTH ART AND CULTURAL HISTORICAL PSYCHOLOGY}

ABSTRACT: This research operates from the theory proposed by Vigotski and reflects how the concept of catharsis can be a tool that produces subjectivity when in association with cinema. The research is constituted in the light of socio-historical psychology and adopts historical-dialectical materialism as a method. For Vygotsky the human is a social being and culture must be interpreted as the raw material for the development of the psyche. It provides us with apparatus and symbolic elements that allow the representation of reality. Thus, the research sought to select nuclei of meaning that could support the discussion about catharsis as a process. The focus group technique was performed with the film "Relatos Selvagens" by Argentine Daminán Szifron as its main instrument, highlighting two cores of meaning: emotion and morality. The first nucleus emotion- was discussed from the Vigotskian conception of emotions and experiences; the understanding of morals as a second nucleus, on the other hand, allowed a dialogue with Sánchez Vázquez's materialistic view of morals. Therefore, since the individual is a being that develops from mediation, cinema can be considered an instrument of cultural transmission, acting concurrently with catharsis in the sensitive transformation of the individual.

KEYWORDS: Art psychology. L. S. Vygosky. Movie theater. 


\section{Introdução}

O presente texto busca provocar uma reflexão a respeito da produção de subjetividade a partir do cinema e sua relação com a dimensão sensível do espectador. O referencial teórico para nossas análises é a psicologia sócio-histórica de Vigotski e seus colaboradores.

A psicologia Sócio-Histórica adota o materialismo histórico-dialético como método, filosofia e também como teoria, trazendo uma possibilidade crítica à abordagem (BOCK, 2007). Mas mais do que isso, concebe o ser humano como um indivíduo ativo, social e histórico; e a sociedade como passível de transformação através da produção histórica dos homens e mulheres - o trabalho. Portanto, a psicologia sócio-histórica aborda o fenômeno psicológico não como algo essencial ou natural ao homem, mas que como uma construção que depende do contexto social, histórico, econômico e cultural em que o indivíduo está inserido. E assim, entender como o mundo externo funciona e se constrói é compreender nosso mundo interior.

A vida material dos homens e mulheres é uma produção advinda do seu trabalho, no entanto vale ainda mencionar a cultura como um acervo de tudo aquilo que foi, também, produzido pela humanidade coletivamente em suas relações sociais. A organização da cultura é necessária para a construção da subjetividade humana - e o cinema, sendo um dos recortes do projeto, mostra-se como um instrumento de mediação e transmissão de cultura contribuindo para que o sujeito tenha outra percepção da vida, transformando seu imaginário e sua subjetividade. Apesar disso, julgo, importante realizar um panorama histórico a respeito de Vigotski e sua psicologia antes de tratar do cinema e sua importância histórica.

Vigotski, nascido em 1896 na Bielorússia (antiga União Soviética), teve suas obras produzidas no contexto soviético pós-revolucionário até meados da década de 1930. A revolução socialista permitiu a construção de uma "nova psicologia" que fosse capaz de superar o antagonismo entre materialismo e idealismo, fazendo com que Vigotski se destaque como um dos grandes intelectuais da sua época.

Sendo assim, Vigotski parte da ideia de que se faz necessária a produção de uma psicologia universal que reúna conhecimentos específicos das diferentes áreas ligadas à psicologia. Para tanto, ele afirma que essa "nova psicologia" deveria tratar da relação que se estabelece entre homem e natureza a partir de uma ótica histórica, dessa forma o homem deve ser visto como produto e também um produtor de si e de sua natureza, segundo ele "Devemos nos considerar unidos e relacionados com o que é anterior a nós, porque inclusive quando o estamos negando, estamos nos apoiando nele" (Vigotski, 1927/1999, p. 405).Por consequência 
dessa nova perspectiva o dualismo seria superado em concomitância com o "novo homem" que o comunismo construiria.

Vigotski, ao longo de sua teoria, se opõe a duas tendências da psicologia. A primeira delas, o subjetivismo, defende que o homem é produto do próprio homem, não sendo influenciado pela sociedade. A segunda conhecida como objetivismo defende que o comportamento humano era influenciado de forma passiva pelo plano social. Assim, Vigotski inova ao dizer que o psiquismo do homem é sócio-histórico, seu desenvolvimento supera a perspectiva do individual para o social e defende uma construção de sujeito do social para o individual.

Desse modo, Vigotski estabelece o raciocínio de que o homem é um ser que constitui uma relação de interdependência com o social - seus processos se dão inicialmente no contexto social e mais tarde partem para um plano intrapessoal, ou seja, individual. Nesse sentido as formas superiores de comportamento estariam fixadas nas relações que o sujeito estabelece com o mundo exterior - as relações sociais.

Vigotski afirma que a cultura deve ser interpretada como a matéria prima do desenvolvimento do psiquismo humano, pois é ela que nos fornece o aparato e elementos simbólicos que permitem a representação da realidade:

Toda forma elementar de comportamento pressupõe uma relação direta à situação-problema defrontada pelo organismo - o que pode ser representado pela forma simples (S R), por outro lado, a estrutura de operações com signos requer um elo intermediário entre o estímulo e a resposta. Esse elo intermediário é um estímulo de segunda ordem (signo), colocado no interior da operação, onde preenche uma função especial; ele cria uma nova relação entre S e R." (VIGOTSKI, 1998, p. 53).

Além disso, para ele, o processo de formação do ser humano assinala duas linhas, a primeira de origem biológica - os processos elementares. E a segunda de origem sócio-cultural - designando as funções psíquicas superiores. É nesse ponto que Vigotski acredita estar presente as relações de objetivação e apropriação do sujeito que ele defende na teoria Histórico-Cultural; o homem se objetiva nos produtos que constrói e assim modifica a cultura. É na apropriação que surgem as características humanas do sujeito, como suas aptidões e qualidades.

Contudo, essa relação que Vigotski afirma existir entre homem e mundo não ocorre de modo direto, mas sim através de uma mediação. E essa mediação existente no processo do desenvolvimento humano advém de signos criados pela própria humanidade; esses signos funcionam como ferramentas da atividade psicológica e possibilita a solução de problemas de 
classe psicológica, como por exemplo, tomar uma determinada decisão. Os signos designam, então, uma representação mental do mundo real.

A mediação por signos, portanto, capacita a construção do pensamento e da linguagem. A linguagem segundo Vigotski seria um signo de mediação essencial para as funções psíquicas superiores, visto que funciona de modo a transmitir conhecimento entre as gerações e auxiliar na elaboração da realidade. Logo, uma de suas funções seria a de diferenciar o homem do animal.

Inicialmente, o que origina a linguagem é a necessidade de comunicação desde os primeiros anos de vida até mais adiante quando a comunicação se torna mais complexa e desenvolvida, "A comunicação só pode ocorrer de uma forma indireta. O pensamento tem que passar primeiro pelos significados e depois pelas palavras." (VIGOTSKI, 1987, p. 129). Para Vigotski a linguagem e o pensamento se desenvolvem de maneiras diferentes e têm origens também diferentes. Quando a criança ainda não domina a linguagem já é capaz de resolver alguns problemas de ordem prática, como alcançar um brinquedo numa estante.

Mais tarde, quando o pensamento e a linguagem se encontram - aproximadamente aos dois anos de idade - o pensamento passa a ser verbal e a linguagem (a fala) intelectual. A linguagem, mais precisamente, atua na expressão do pensamento e na organização dele; a primeira atuação diz respeito à comunicação e a segunda à generalização.

Além do pensamento e da linguagem, Vigotski aborda também em suas obras as emoções. E é nesse ponto que pretendo relacionar o cinema com dimensão sensível do sujeito e para tanto usarei como base uma das obras de Vigotski - A Psicologia da Arte. Apesar de em suas obras Vigotski não abarcar a respeito do cinema como um recorte das artes, tentarei a partir de seus estudos realizar uma reflexão sobre a sétima arte e a concepção de catarse, a qual Vigotski conceitua em seu livro citado anteriormente.

Diferente da literatura, por exemplo, o cinema surge em uma data estabelecida - 28 de dezembro de 1895 - e por intermédio dos irmãos Luis e Augusto Lumiére foram feitas as inúmeras tentativas de reproduzir para a sociedade o movimento dos objetos. O cinema surge em um contexto em que há um grande número de homens que não frequentam os teatros caros e grandes espetáculos, portanto, constitui aos finais do século XIX uma forma alternativa de entretenimento para os aglomerados humanos.

Assim, o homem passa a ser controlado também fora das fábricas, agora nos circos e ambientes de lazer a mente do homem industrial era também padronizada. Como consequência, anos mais tarde, o cinema se torna uma das atividades mais vigorosas do capitalismo. Logo, é de extrema importância que se guarde o contexto em que o cinema nasce pois representa a vida 
moderna industrializada e urbana que exige novas formas de comunicação, e que buscam transformar a subjetividade do homem dessa época.

O cinema constitui um conjunto de signos mediadores e através dele é possível a objetivação da atividade social e da linguagem - fornece-nos um meio de formação imagético de acordo com a teoria Sócio-Histórica. De certo, além de ser produto de uma indústria cultural de seu contexto adventício, o cinema também se entende como manifestação artística. E como uma manifestação artística o cinema também suscita emoções no espectador, a isso reconhecemos como "reação estética". Após passar pelo processo criativo do cineasta e chegar às telas dos cinemas e TV's a obra cinematográfica proporciona ao espectador uma dimensão formativa de catarse e outra deformativa de anticatarse, uma contradição emocional, "E conclui que a catarse consiste em uma emoção ou afeto que se desenvolve em dois sentidos opostos e encontra sua destruição em um ponto culminante, numa espécie de curto-circuito." (VIGOTSKI, 1999, p. 17).

E aqui, faço uma pausa para aprofundarmos a discussão a respeito das emoções nos escritos de Vigotski; e posteriormente sobre catarse, também na ótica do mesmo teórico. Devemos novamente partir da ideia de que o psiquismo humano é social já que o ser humano só se faz humano na relação social que estabelece com os outros e o mundo; e nessa relação encontramos a linguagem e o pensamento como mediadores dessa relação construtiva.

A partir de algumas pesquisas debruçadas sobre as obras de Vigotski, constatou-se a importância das emoções no processo de mediação assim como a linguagem e o pensamento. Uma dessas pesquisas, como a de Sawaia (1987) realizada em favelas e com entrevistamento das mulheres de lá, observou que as mulheres mencionavam as emoções que estavam sentindo quando conversam entre si. A consciência, portanto, seria movida pelas emoções e levada a reflexão e ação como apontou Lane (1995).

Assim, nota-se que as emoções possuem de fato um caráter social e comunicativo. Sendo as emoções construídas por meio do plano social ocorre a existência do emissor e receptor. Nesse sentido, o cinema, assim como outras formas de comunicação em massa que atuam sobre o psiquismo e dão subsídios sociais para o desenvolvimento das emoções, deve ser analisado como atuante na dimensão sensível do receptor.

De certo, assim como a linguagem e significados se desenvolvem na história e também através dela, as emoções também o fazem. Mas além de se relacionar à consciência como já mencionado anteriormente, as emoções também se relacionam com o inconsciente, como demonstrou Vigotski em sua obra A Psicologia da Arte (1971). Nessa obra Vigotski menciona 
a emoção estética do receptor da arte produzido no momento em que a obra e o conteúdo entram em contradição.

Para Vigotski, a arte assume um papel de produto da realidade objetiva e se constrói por assim dizer a partir do trabalho do homem e seu processo de imaginação criativa. $\mathrm{O}$ que impulsiona esse movimento dialético da arte seria a catarse. Para ele, então, as emoções sentidas pelo receptor no momento catártico, em que a forma e o conteúdo entram em contradição, irão se transformar em novas emoções. Mas, mais do que isso as emoções contraditórias serão impulsionadas graças aos signos e sua mediação quando os elementos do conteúdo da obra são colocados em relação. Por assim dizer "[...] processo que gostaríamos de definir com o termo catarse. Poderíamos mostrar que o artista sempre destrói o seu conteúdo pela forma [...] a oposição entre a estrutura da forma artística e o conteúdo é o fundamento do efeito catártico da reação estética" (Vigotski, 1999, p. 271).

Destarte, ao longo da pesquisa será buscada uma relação existente entre a teoria de Vigotski e sua concepção a respeito da reação estética - a catarse - gerada pelo cinema e como este age no sujeito propondo uma transformação em sua dimensão emocional. Como bem menciona Toassa em seu livro "Emoções e Vivências em Vigotski”, a parte-todo da obra de arte permite que ela seja vista como um amontoado de contradições capazes de produzir no receptor a reação estética (TOASSA, 2011), e é a esse todo que o receptor conferirá suas emoções e interpretações particulares.

Para tanto, a pesquisa se utilizará da técnica de grupo focal para analisar a transformação de afetos dos sujeitos diante de uma obra de arte - a saber, um filme. Assim, foram escolhidos dois capítulos do filme Relatos Selvagens e posteriormente apresentados a um grupo de 6 voluntários que também participara de uma discussão a respeito do filme. A discussão foi transcrita e através do material coletado levantados pré-indicadores que deram origem a indicadores que possibilitaram a formação dos núcleos de informação da pesquisa.

\section{Metodologia}

Foi utilizado como material para análise e discussão o filme "Relatos Selvagens" considerado uma produção do gênero thriller e drama. A trama do filme gira em torno de seis histórias independentes - todas bastante regulares, algo raro no gênero -, unidas por protagonistas fora de controle, que decidem fazer justiça com as próprias mãos. Assim, as histórias tratam da ansiedade que é motivada por pequenos detalhes do cotidiano. Os cenários 
temáticos do filme são os passageiros de um avião, uma lanchonete de beira de estrada, motoristas numa estrada, um pai de família azarado, um casamento e uma negociação dramática. $\mathrm{O}$ humor sofisticado e inteligente é a principal característica do filme escrito e dirigido por Damián Szifron em forma de ontologia. O longa traz em seu elenco Ricardo Darín, além de outros excelentes atores como Oscar Martínez, Diegos Gentiller e Erica Rivas. A produção argentina em parceira com a Espanha sob o selo da compania dos irmãos Pedro e Agustín Almodóvar, além de ser a única produção latino-americana a entrar para a competição oficial do Festival de Cannes, também foi o candidato argentino no Oscar de 2015 na categoria de melhor filme estrangeiro. O filme foi lançado em 2014 e conta com 122 minutos (2h e 2 minutos) de duração e com uma classificação etária de 14 anos. Para que se pudesse compreender o conceito de catarse que Vigotski propõe e como ocorre o efeito catártico entre o filme e o telespectador, foi realizado um grupo focal que reuniu seis estudantes voluntários com idades acima de 18 anos. Ademais, por ser realizada com a participação de voluntários a pesquisa foi aprovada pelo comitê de ética em pesquisa com seres humanos. O grupo focal teve como finalidade uma discussão estruturada e mediada por um facilitador que guiou a discussão através de perguntas, esclarecimento de dúvidas e respostas alcançando os objetivos listados no projeto. O método foi, portanto, organizado de modo que o filme selecionado fosse apresentado aos voluntários em um dia e horário específicos em uma sala de vídeo da universidade e posteriormente foi realizada a discussão entre os participantes. Ao fim do filme foram feitas, por mim enquanto facilitadora, perguntas simples e disparatórias para incentivar a discussão como: "o que você sentiu assistindo ao filme?"; "o que você faria nessa situação?"; " Vocês acham que as reações dos personagens, elas vêm de vivências anteriores?"; " Quais questões sociais vocês acham que estão envolvidas?". A atividade foi gravada e filmada para transcrição e análise que seguiu os seguintes passos: leituras flutuantes, levantamento dos pré-indicadores, indicadores e a formação de núcleos de significação obtidos em um contexto (OZELLA \& AGUIAR). Dessa forma a análise do material qualitativo teve como objetivo compreender os sentidos que contribuem para o conteúdo de um discurso de sujeitos por meio dos núcleos de significação já mencionados e que fazem parte da teoria sócio-histórica. Portanto, vale salientar que partimos de palavras que se inserem em um contexto que possam lhe atribuir significado aqui, o contexto deve levar em consideração a narrativa do sujeito e todas as condições histórico-sociais que o complementa. Os pré-indicadores permitem surgir diferentes temas responsáveis pela construção dos núcleos de significação para a pesquisa. Esse processo teve como foco avançar do empírico para o interpretativo, visto que também para Vigotski (1998) a fala exterior abre caminho para um plano interior. 


\subsection{Resultados e discussão}

Como resultado da metodologia aplicada na pesquisa, obtive alguns núcleos de significação subsidiados por meio da técnica de grupo focal, a qual serviram como base para a seleção de pré-indicadores. Para tanto, foi preciso tomar a palavra como significado de uma primeira unidade a ser destacada no momento empírico da pesquisa, com a intenção de se analisar o sujeito (AGUIAR \& OZELLA, 2006). A partir da leitura flutuante da transcrição do grupo focal foram surgindo e sendo organizados pré-indicadores que apareciam como temas diversos e que foram classificados pela importância dada pelo próprio sujeito em sua narrativa, a frequência em que se repetiam no discurso e também pela carga emocional. A saber, alguns exemplos de pré indicadores observados durante a leitura do material: "John - Eu achei agoniante, mas ao mesmo tempo, tipo, o primeiro, por exemplo, ele era agoniante e ficava de boa, do nada. Parecia que eu tava num bem estar "cabreiro", tipo, porque você "tava" cabreiro porque era uma situação "cabreira" mas do nada tinha uma músiquinha de boa ou sei lá, um negócio engraçado."; "John - É, no começo é uma situação meio cabreira, ele passa e chinga o cara, daí continua uma música de boa e ele dirigindo."; "Eva - É que eu senti que no primeiro algumas situações se tornavam confortáveis porque tinha uma música ali." Nesse caso, as falas expostas acima representam um pré-indicador que apareceu com frequência na narrativa dos voluntários, além disso foram aglutinados por apresentarem uma complementariedade entre si. Já outros pré-indicadores foram classificados por similaridade, como é o caso do diálogo que se segue:

Amélia - Acho que eu ia ficar ligando pra polícia.

Eva - Eu não ia me colocar no meio, acho que seria impossível sobreviver.

Amélia - Eu ia ficar desesperada de ver o cara "cagando" lá.

John - "Se pá" ia só ficar de fora tentando ligar (parte inteligível pois todos falam juntos). Eu ia ficar curioso, na real.

Ainda houveram pré-indicadores aglutinados por contraposição, um exemplo disso aparece em seguida:

Nova - Eu não tinha me tocado!!!

Eva - Foi o marido da mulher que matou.

Soko - Ele apareceu na tv falando que ia achar o cara.

Amélia - Não! O marido da grávida que morreu que matou o José.

Nova - Ah tá! 
Com essa aglutinação foi possível a organização dos indicadores de significação. Alguns desses pré-indicadores foram música, sensação de aflição e surpresa, moral, corrupção, generalização, masculinidade, dinheiro e economia. A partir desses indicadores, foi feito seguindo Aguiar \& Ozella (2001), um retorno ao material da transcrição para uma seleção de trechos que esclarecem os indicadores, visto que um mesmo indicador pode ter diferentes potências como no caso do indicador dinheiro.

É através dessa clivagem e articulação que se inicia a construção e a análise dos núcleos de significação e sua organização através da nomeação dos núcleos. A classificação e aglutinação dos pré-indicadores por similaridade, complementariedade e contraposição mencionada anteriormente, fora de suma importância para revelar a essência dos conteúdos encontrados no discurso dos participantes.

Os núcleos de significação são indispensáveis para o resultado da pesquisa visto que expressam pontos centrais e fundamentais "que trazem implicações para o sujeito, que envolvam emocionalmente, que revelem as suas determinações constitutivas" (AGUIAR \& OZELLA, 2001, p 231). Dado isso, os núcleos de significação extraídos do processo foram emoção, percepção e moral. Mais tarde, após uma análise mais adequada e ratificada, propus que o núcleo emoção e percepção poderiam fundir-se em um só - emoção- já que ambos estariam intimamente ligados do ponto de vista sócio-histórico.

\subsection{Núcleo de significação: emoção}

Como dito na seção anterior, emoção foi um dos núcleos de significação levantados durante o processo, esse núcleo foi um dos temas abordados na teoria de Vigotski que debruçouse sobre o estudo da gênese das reações estéticas. Segundo ele, a arte seria um produto social com o objetivo de estimular determinados efeitos no sujeito, ela se converteria de um elemento social para um pessoal (TOASSA, 2011).

A arte pode ser considerada, segundo Vigotski (2001) um conjunto singular de contradições e de interações que promovem a reação estética de quem experimenta a obra de arte, cada apreciador acrescentaria, então, suas interpretações e emoções. O autor ainda indica que o impacto da arte nunca será igual para cada receptor, entretanto, o psicólogo da arte poderia analisar as leis de construção que o produzem de maneira geral.

Para Vigotski (2001) a transformação das emoções externamente a nós seria possível através de um sentimento social que se materializa nos objetos de arte e que, consequentemente, 
se tornam objetos sociais. E também, num sentido inverso e mais íntimo da vivência artística. Portanto, ao interagirmos com uma obra de arte estamos estabelecendo uma relação social que não se trata de um contágio emocional ou imitação de afetos, mas sim uma transformação de afetos comuns realizada pela catarse ou reação estética, como indica Toassa (2011). Logo, a interação e transformação através da obra de arte não dá-se num aspecto individual, mas social por meio do sentimento social objetivado e materializado no mundo externo.

Toassa (2011) traz à tona a discussão sobre a socialidade artística que fornece respaldo para a existência material de emoções incomunicáveis e que adquirem sentido na arte. A socialidade pode ser, então, um importante veículo para universalizar emoções íntimas, visto que as emoções experimentadas na vivência artística são próprias da pessoa e podem vir a se transmutar e generalizar no vivenciamento da arte por meio de catalise de novas emoções. Toassa (2011, p.60) ainda diz que:

Um outro aspecto mencionado por Toassa (2011) é a comunicação entre as pessoas a respeito dos efeitos da arte e de sua natureza. Isso, segundo Vigotski seria um significativo efeito intelectual-afetivo nos sujeitos, assim "uma obra pode ser estopim da troca de ideias sobre sentimentos que transmutaram de sentido" (TOASSA, 2011). Por isso, pode-se dizer que Vigotski acredita que das emoções estéticas decorrem resultados indiretos motivados pela generalidade da emoção em diferentes campos artísticos. Um filme, por exemplo, como o que foi apresentado na técnica de grupo focal desta pesquisa, desencadeou um estado de aflição e indignação nos receptores.

O autor russo classifica as emoções, então, como uma função parcial do sistema totalizante, assim, ao meu ver, o total ficaria restringido à consciência e personalidade, por exemplo. No entanto, o grande entrave que Vigotski enfrentaria seria a ideia, já antiga na psicologia, de que o campo das emoções se tratava de algo irracional ou somático. Era essa referência negativa das emoções na psicologia que Vigotski criticou, pois para ele as emoções teriam diferentes potenciais criativos e culturais (VIGOTSKI, 1996).

$\mathrm{Na}$ presente pesquisa, ao entrarem em contato com o filme, os voluntários do grupo focal tiveram suas funções superiores colocadas em movimento, pois a obra objetiva suscitar emoções que são transformadas em sentimentos pela catarse e se reorganizam em uma estrutura de consciência mais complexa. Assim, considera-se que a arte permite transformações na medida de generalidade da consciência ou, como explicam Barroco e Superti (2014), podem provocar um salto qualitativo das relações de generalidade das funções psicológicas superiores.

Ainda na construção do núcleo de significação da emoção, acreditamos ser pertinente lançar mão do conceito de vivência para Vigotski, ou perejivânie. Tal conceito, assume ao lado 
dos afetos e dos sentidos grande importância no entendimento da construção histórica do sujeito. A categoria perejivânie é ainda pouco estudada e analisada no Brasil, no entanto aparece nos textos pedológicos de Vigotski como uma unidade essencial para o desenvolvimento da consciência numa situação social.

De acordo com os estudos de Toassa $(2010,2011)$ perejivânie seria em português a tradução do termo russo que deriva do par de verbos russos perejit e perejivát, os dois se originam do verbo jit que se traduz como viver. Segundo Toassa a tradução de perejivânie se aproxima das palavras viver, presenciar, sofrer, suportar ou aguentar. Entretanto, no português a tradução mais adequada para esse termo seria vivência.

Nesse ponto, é preciso estabelecer diferenças entre a vivência e a experiência, haja vista que experiência são situações pela qual o sujeito passa sem que estas impactem seu desenvolvimento. Por outro lado, a vivência seria capaz de transformar o sujeito e sua relação com a realidade que lhe é dada, assim nossa atitude diante à relação vivida seria transformada.

A categoria perejivânie aparece inicialmente no trabalho de Vigotski intitulado "A Tragédia de Hamlet, príncipe da Dinamarca” nos anos de 1915/1916. Posteriormente, em sua obra Psicologia da Arte (1915/1922), Vigotski assume perejivânie como uma unidade para explicar os processos psicológicos que advinham da arte, como por exemplo o processo catártico abordado na presente pesquisa.

No texto A Questão do Meio na Pedologia (2010, p. 686), Vigotski nos permite entender a vivência da seguinte maneira:

A vivência é uma unidade na qual, por um lado, de modo indivisível, o meio,
aquilo que se vivencia está representado - a vivência sempre se liga àquilo
que está localizado fora da pessoa - e,por outro lado, está representado como
eu vivencio isso, ou seja, todas as particularidades da personalidade e todas as
articularidades do meio são apresentadas na vivência, tantoaquilo que é
retirado do meio, todos os elementos que possuem relação com dada
personalidade, como aquilo que é retirado da personalidade, todos os traços
de seu caráter, traços constitutivos que possuem relação com dado
acontecimento.

Podemos admitir que a vivência de cada voluntário do grupo focal foi diferente levando em consideração a forma como o termo perejivânie é concebido por Vigotski. Podemos notar essa diferença na forma de ser afetado ou afetada pela situação ao ler a transcrição do grupo focal em que cada sujeito se comportou ou reagiu de modos diferentes em relação aos mesmo recortes do filme - alguns deles relataram surpresa e agonia, por exemplo.

Para o bielorruso as vivências representariam a ponte entre personalidade, consciência e meio. Segundo Toassa e Souza (2010), no processo de ontogênese as vivências assumem o 
papel de unidade dinâmica da consciência e personalidade e se dinamizam em dois núcleos, a saber: núcleo interno, que aglutina as fantasias, as lembranças e processos mentais que não estão conectados a realidade objetiva; e o núcleo externo que consiste na percepção dos objetos. E assim, o processo de tomada da consciência de si no mundo se dá no desenvolvimento de vivências. Portanto, "a vivência torna-se unidade sistêmica da vida consciente, marcada pela referência ao corpo, às representações e ideias, ou ao mundo externo; com a atividade dominante desta ou daquela função psíquica” (TOASSA \& SOUZA, 2010, p. 771).

Ao se falar em vivência, retomamos os conceitos de significado e sentido. Em seu livro A Construção do Pensamento e da Linguagem, Vigotski (2001) identifica o significado como a generalização ou um conceito. Ao realizar atividade no mundo, transformar e ser transformado o homem produz significados, por assim dizer, a atividade humana é significada em todos os casos. Assim, a internalização se dá através das significações que podem transformar algo natural em cultural (Aguiar \& Ozella, 2013). Desse modo, podemos considerar a categoria de significado muito importante durante realização do grupo focal, visto que os voluntários compartilharam entre si suas experiências e, em especial, suas vivências na discussão após assistirem os recortes do filme. No entanto, é o sentido que difere aquilo que foi compartilhado entre os sujeitos do grupo focal, evidênciando a singularidade de cada um deles.

Logo, diferente do significado que é algo estável e generalizado, o sentido se adequa a um campo mais subjetivo e com potencial transformador. Podemos dizer que no grupo focal, por exemplo, um núcleo de significado foi equipado por diferentes sentidos a medida que cada voluntário do grupo compartilhava sua vivência em relação as cenas assistidas. Como por exemplo quando a mediadora pergunta o que os voluntários senstiram ao ver as cenas e eles dizem:

pesquisadora - a primeira pergunta é o que vocês sentiram assistindo os dois epsódios?

Amélia - Nossa, eu fiquei meio tensa assim.

Soko - Nervoso.

Eva - Ah, eu me assustei bastante em vários momentos.

John - Foi um crime pacional, né.

Nova - Mas é uma sensação de "cabreiro".

Pode-se perceber nesse momento uma ativação do pensamento emocionado dos participantes a

partir do filme através da mudança de significados e a possibilidade de avançar em direção aos sentidos pessoais a respeito de temas socialmente estabelecidos como a violência e agressividade, 
tratada na primeira cena apresentada aos estudantes; e a moral na segunda cena.

pesquisadora - Vocês acham que dá pra gente pensar no segundo episódio como uma questão moral e por isso se sentir mal vendo?

Nova - É, acho que é porque deu tudo errado, sabe?

Soko - O primeiro episódio é mais, tipo, bizarro. E o segundo é mais, né, moral.

Nina - Eu não sei, acho que o segundo ele aproxima uma situação mais real, e o primeiro é tão bizarro que sei lá, não parece que vai acontecer e tem um tom engraçado às vezes. É como eles falaram é bizarro, engraçado.

Levando em conta ainda a teoria vigotskiana, a tomada de consciência que se dá dialéticamente com a vivência pressupõe que uma mesma situação terá para diferentes sujeitos sentidos, também, completamente diferentes. Como se vê na seguinte transcrição:

Pesquisadora - Qual dos dois casos vocês acham que é o mais comum? Que é mais fácil de acontecer?

Nova e John - O segundo.

Amélia - Mas o primeiro também é.

Nova - Briga na estrada é muito comum, eu imagino. Mas daquela proporção...

John - Ele torna bem bizarro, né.

Eva -Ele leva ao extremo, literalmente. As coisas se desdobrariam de um jeito diferente.

John - Mas o segundo rola todo dia. Tem vários casos.

Para Aguiar \& Ozella (2013), o sentido aponta para a necessidade que por vezes ainda não se realizou, mas que mobiliza o sujeito e determinam a forma em que este sera colocado em ação, destacando suas singularidades constituídas dentro de sua historicidade, ou seja de suas vivências até então. Por exemplo:

Pesquisadora: Vocês já viram situações parecidas? De alguém fazendo algo parecido, onde vocês sentiram algum medo ou alguma sensação que tiveram assistindo ao filme?

Soko: Tipo no carro?

Pesquisadora: Não, algumas situações similares que sentiram a mesma coisa, um desconforto, uma náusea...

Amélia - Tem a Richthofen, também, que matou os pais por dinheiro.

Nova - É verdade. Mas no do carro... atropelou, vazou e não foi preso, entendeu.

John - Tem um cara de Maringá que tipo, não sei se é esse que você tá falando. Ele é ricasso, e ele tipo, tava bêbado e matou, acho, um casal. Sei quem que é, mas tipo... E daí o pai dele é juíz, um negócio assim. E não deu nada. Não houve mais nada sobre. É um negócio que 
rola muito, na real, no direito criminal. E de trânsito, eu lembrei de uma vez que a gente tava saindo daquela cervejada e tipo começaram a tretar um monte de carro. A gente achou que a galera ia se matar, mas no final não deu nada. Mas nossa, fiquei morrendo de medo.

Nova - O cara saiu e... Sim! Era na Chácara Vitória. A gente tava indo a pé pra chegar onde minha mãe tava de carro.

John - Tinha um cara que tava falando do lado da gente. Acho até que falou comigo. Tipo, um bêbado saindo de cervejada. Aí passou um cara e quase atropelou ele, assim. E eles começaram a discutir um monte. $\mathrm{O}$ cara ficou indo, tentando atropelar ele. Nossa, foi cabreiro.

Pesquisadora - E o que vocês pensaram em fazer? Vocês ficaram quietos?

John - Eu fiquei, tipo, paralisado, do lado!

Como foi dito, ao se expressar em suas ações e em sua atividade, o homem expressa também suas singularidades e particularidades ao mesmo tempo que produz seus significados e sentidos (Aguiar \& Ozella, 2013). O singular pode expressar, portanto, dimensões consideradas plurais naquilo que a constitui. E o plural poderia, segundo Aguiar \& Ozella (2013) deflagrar uma articulação com as diferentes singularidades a partir das quais se é produzido. Entende-se assim, que o homem é um ser social e singular que se constitui através de diferentes relações entre o social ou universal mediadas pelo particular e singular.

Aqui, novamente a mediação se faz importante, como foi no início desta pesquisa, essa categoria garante uma relação entre os objetos, processos e situações de modo que além de ligar a singularidade à universalidade, permite a organização central dessa relação dialética. E o cinema, é um importante signo de mediação que realiza exatamente essa função de integrar o singular e o universal na produção de vivência e reação estética. Desse modo, podemos entender a importância do cinema, enquanto signo de mediação, para a presente pesquisa de acordo com Aguiar \& Ozella (2013, p.303, apud AGUIAR, 2002, p.129), “Os signos, entendidos como instrumentos convencionais de natureza social, são os meios de contato com o mundo exterior e, também do homem consigo mesmo e com a própria consciência.”. Assim nas relações mediadas na sociedade, o sujeito produz e a transforma, ao mesmo tempo que também é transformado por ela.

\subsection{Núcleo de significação: moral}

Para estabelecer uma possível discussão à respeito da moral como núcleo de significação desta pesquisa terei respaldo nos estudos de Vásquez e Vigotski. Início, portanto, mencionando a questão da interiorização ou reconstrução dos valores morais pela criança, além 
do papel dessas estruturas mentais já estabelecidas pela interiorização nos estudos desenvolvidos por Vigotski (1960/1987). Como ressalta Nunes e Branco (2007), a existência de regras morais nos códigos obrigatórios de cada comunidade não deve ser vista como valores morais universais ou desvinculados da realidade, pois esses valores são compartilhados por diferentes culturas devido sua importância para o estabelecimento do convívio de sujeitos em diferentes contextos sociais.

Assim, entendemos que o processo de desenvolvimento da moral é um processo de transformação qualitativa que ocorre através das interações e relações dialéticas entre indivíduo e ambiente social. Essa relação dialética deve ser entendida, segundo Nunes e Branco (2007) como uma relação complexa e dinâmica em que tanto o sujeito como o ambiente se transformam concomitantemente. Dado isto, os conceitos de internalização e externalização são essenciais para entender a relação entre indivíduo e sociedade.

A internalização se refere aos mecanismo de tornar intrapsicológico o que é interpsicológico (VIGOTSKI, 1960/1987), além disso o teórico explica que o desenvolvimento cultural do sujeito ainda enquanto criança ocorre em dois momentos: um no plano das relações sociais e outro que se dá a nível de categoria intrapsíquica. Já a externalização constitui os mecanismos do sujeito ao participar das transformações em contexto sociocultural. Os elementos socioculturais, como bem pontuam Nunes e Branco (2007) são internalizados pelo sujeito e depois externalizados a ponto de configurar as relações sociais e introduzir novos elementos da cultura como a moral, por exemplo.

A cultura coletiva, portanto, reflete os significados que são compartilhados por diferentes grupos dos quais os sujeitos participam. Nesses significados podemos encontrar as normas, regras sociais e práticas de uma sociedade que são internalizadas pelo sujeito e podem ser considerados como "sentidos", segundo Vigotski (1960/1987), ou também como cultura pessoal. Na transcrição do grupo focal esse proceso de aprofundamento dos significados em sentidos a respeito de uma tema social como a moral fica evidente da seguinte maneira:

Nova - Nossa, a segunda dá um enjôo “assim”, náusea, é nauseante. Dá até uma agonia quando no fim lá o menino quer se entregar e daí o José vira e fala assim “ei, não".

Soko - No começo eu tava com dó do José, mas ele começou a pedir dinheiro, não tava nem aí.

Amélia - Todo mundo é bem corrupto. E quem matou ele foi o marido da mulher, não foi?

John - Mas o segundo rola todo dia. Tem vários casos. 
Eva - É verdade. O quanto de gente que tem atropelando gente e fugindo. E o que que acontece com essas pessoas? Isso acontece todo dia.

A cultura pessoal é uma releitura singular da cultura coletiva externalizada e que é alterada ao longo do tempo rompendo-se padrões socialmente construídos (Nunes e Branco, 2007). Os valores morais de uma cultura podem, portanto, orientar o comportamento dos sujeitos possibilitando um sentido para suas ações dentro de uma cultura, esses valores podem ser modificados a partir de experiências emocionais ou visões de mundo predominantes em uma determinada época.

No estudo do grupo focal, pode-se classificar a moral como um núcleo de significação que apareceu inúmeras vezes durante a discussão do filme nas falas dos participantes. Alguns exemplos dessas falas apresentaram elementos generalizados como se segue:

Pesquisadora - Quais questões sociais vocês acham que estão envolvidas? Você já disse do machismo, racismo...

John - Corrupção, orgulho...

Amélia - Capitalismo.

Eva - Sim, "vai arruinar a minha vida. Não quero me incomodar com isso, então vou dar dinheiro, sabe. É tudo questão de orgulho, o tempo todo".

Percebe-se, então, que o filme permitiu a mobilização de afetos relacionados aos temas orgulho, corrupção e dinheiro que podem ser facilmente relacionados ao núcleo de significação moral. Assim, pode-se estabelecer uma relação entre a experiência emocional mencionada anteriormente e a mobilização e transformação de afetos ligados a valores morais nos participantes do grupo focal. Houve portanto a transformação da moral da cultura pessoal e a introdução de novos elementos na cultura coletiva a partir da internalização e externalização durante o grupo o grupo focal.

Segundo Vázques (2002), a moral se desenvolve ao longo do tempo e de acordo com as interações histórico-sociais; o desenvolvimento da moral deve ser visto, portanto, como independente do progresso histórico e social. Como exemplo de progresso histórico e social, Vazqués (2002) menciona o desenvolvimento da produção de bens culturais como a ciência e arte, essa atividade produtiva e social que permeia a produção de arte pode ser um importante critério para avaliar o homem como um ser social. Haja visto o que foi mencionado anteriormente a respeito do sentimento social objetivado e materializado como arte externamente a nós na produção humana, o que qualifica a experiência de vivência em relação à arte algo que transcende o campo individual. 
Vazqués (2002) também considera o desenvolvimento moral a partir da negação e reafirmação de diferentes elementos como a "solidariedade", por exemplo, que adquire um valor universal. Pode-se notar esse elemento na discussão realizada durante o grupo focal, e também outros elementos universais como o “interesse”. Percebe-se, então, como a moral regula e modela os comportamentos individuais e coletivos do sujeito.

É importante, no entanto, compreender que a moral é essencial para o controle social de grupos e pessoas, ela é, por assim dizer, um ato concreto em um contexto normativo em vigor em determinado grupo social que lhe confere sentido. O sujeito, como diz Vazqués (2002), tem sua ação e decisão emanadas de si, agindo livremente e conscientemente através de sua responsabilidade individual. Entretanto, o indivíduo não age exclusivamente respondendo a sua “voz interior", mas também influenciado pelo mundo social do qual faz parte. Seria, então, uma consciência pessoal que interioriza as regras e valores normativas do grupo social.

Em contrapartida temos a emoção, o primeiro núcleo de significação, que pode ter grande influência e ser considerada como um risco para a racionalidade que permeia a moral. Como foi dito ao longo da discussão dos núcleos de significação, nossa forma de sentir está diretamente ligada às condições objetivas que nos são apresentadas, assim o filme Relatos Selvagens coloca mais de uma vez a moral individual em contradição com o "ideal de moral", $\mathrm{o}$ aspecto normativo dos valores.

Essa contradição mencionada ocorre por meio da catarse que permite que as cenas apresentadas ao participantes do grupo focal gerassem certo desconforto emocional que afetou diretamente os valores morais como nas seguintes falas dos participantes do grupo focal:

Soko - O segundo é engraçado, porque o cara tá disposto a dar dinheiro, sabe. Dá dinheiro para "pô, meu filho não vai ser preso". Quando começam a pedir muito, é demais pra ele. Vai o filho preso $\operatorname{logo...}$

John - Inverte os valores.

Nova - Mas aí de novo, o problema foi o cara tá enganando ele mais do que o dinheiro. Porque o dinheiro sim, mas o orgulho...

John - Os dois acho que tem muito de orgulho.

Percebe-se, portanto, que as funções psicológicas existem interligadas uma a outra, ao afetar-se a emoção afeta-se a moral ao passo que a arte toca e ativa o pensamento emocionado do sujeito atravessando as barreiras da moral, partindo dos significados já estabelecidos socialmente e fazendo emergir e desorganizar os sentidos pessoais de quem vivencia determinada situação. 
É importante levar em consideração o fato de que o processo histórico e social pode afetar a moral de modo negativo ou positivo, assim pode acentuar um progresso positivo da moral, mas também negativo como a violência e a degradação da moral. A degradação da moral se evidência no filme apresentado na realização do grupo focal e possibilitou a compreensão de como temas ligados a moral têm seus significados transformados em sentidos a partir da desorganização destes e das emoções. Como exemplo de um pregresso histórico e social que altera a esfera moral, pode-se citar o capitalismo e até mesmo o surgimento do cinema, acarretando uma transformação e degradação da moral operária (VAZQUÉZ, 2001).

Em suma, podemos concluir que a moral como uma forma de comportamento humano está impregnada por um caráter social, visto que é uma característica de um sujeito que mesmo ao se comportar individualmente se manifesta como um ser social (VAZQUÉZ, 2001). Assim, a moral é capaz de regular o comportamento individual do sujeito que pode afetar a outros, mesmo que a moral seja, ela própria, influênciada pelos processos históricos e sociais. A moral se incumbe, portanto, de regulamentar a relação entre os seres sociais.

A moral, através de seu caráter social, implica em uma relação dialética entre sujeito e comunidade. Pois, desde a infância e durante o processo de internalização o indivíduo se vê influenciado socialmente por meio dos pais, da escola, dos amigos e meios de comunicação e arte, em especial o cinema. É, a partir dessas influências e signos externos que, aos poucos, o sujeito constrói suas ideias morais e seus modelos de comportamentos morais (VAZQUÉZ, 2001).

Mas ainda que a moral seja social, o sujeito ao se comportar moralmente desempenha um papel essencial através da interiorização de normas e deveres, logo, o significado de moral se aprofunda até que as emoções sejam ativadas e que os sentidos se desorganizem quando uma situação específica nos leva, por exemplo, à reação estética e assim novos sentidos pessoais são atribuídos às vivências e situações sociais. Assim durante o grupo focal, os participantes ao entrarem em contato com um filme atravessado por questões sociais como violência, agressividade, orgulho e corrupção vivenciaram o conceito de catarse estabelecido por Vigotski e tiveram suas emoções e afetos contrariados e desorganizados até que finalmente pudessem estabelecer novos sentidos.

\section{Considerações finais}

A pesquisa partiu da compreensão do conceito de catarse para Vigotski como uma categoria psicológica mediadora. Nesse sentido, tal categoria permitiria a transformação da 
dimensão sensível do sujeito e a formação de uma individualidade para-si. Além disso, a pesquisa dialogou com a sétima arte através do cinema, visto que a arte é um instrumento também mediador e facilitador da reação estética que Vigotski menciona como uma técnica social do sentimento, ao passo que permite a transformação de uma experiência em vivência.

Para alcançarmos o objetivo, utilizamos a técnica do grupo focal, posteriormente analisada sob o método de construção da informação. Pudemos entender no decorrer da pesquisa que uma vivência estética nem sempre se faz a partir de um conteúdo totalmente prazeroso, exigindo do espectador um constante conflito entre seus afetos distintos e uma tensão frente ao que lhe é apresentado. O momento de contradições, mencionado por Vigotski ao longo desta pesquisa, leva o receptor a novas percepções a respeito de sua realidade externa e também interna.

A metodologia utilizada nesta pesquisa permitiu que ao longo do trabalho fosse possível aprofundar a discussão a respeito não somente da catarse em si, mas de dois núcleos de significação essenciais ao processo de reação estética. O primeiro núcleo trabalhado, emoção, é de grande relevância nos estudos de Vigotski, visto que se constituem a partir de um plano social e assim como a linguagem e os significados, as emoções também se desenvolvem através da historicidade.

A transformação das emoções externamente a nós seria produto de um sentimento social materializado em objetos da arte como, por exemplo, um filme que se tornaria, então, um objeto social. Pode-se concluir, portanto, que a relação entre receptor e cinema é social e os afetos se transformam pela catarse. Ou seja, a transformação do sujeito a partir da reação estética não pode ser vista apenas como individual, mas de fato como social, dado o sentimento social que se objetiva e se materializa no mundo externo ao inidivíduo. Através do presente trabalho, pudemos compreender que as emoções devem ser identificadas não somente como fenômenos internos ou externos a nós, mas sim como uma função social e que está diretamente ligada ao contexto histórico.

O núcleo moral foi essencial para compreendermos que o processo de desenvolvimento da moral se dá através de relações dialéticas entre sujeito e ambiente social, e também por meio da internalização. A moral apareceu inúmeras vezes na realização e discussão do grupo focal, o que permite dizer que houve a mobilização de afetos relacionados a temas que tangem a moral como a corrupção, orgulho e dinheiro. E, portanto, a transformação da moral pessoal e introdução de novos elementos no coletivo por meio de internalizações e externalizações durante o grupo focal. 
Em conclusão podemos afirmar que os objetivos traçados no início da pesquisa como: a compreensão do conceito de catarse para Vigotski e como a reação estética transforma a dimensão sensível do telespectador foram atendidos. A realização do grupo focal e o consequente aprofundamento de significados em sentidos pelas vivências dos voluntários permitiu que a pesquisa pudesse discutir dois núcleos de significação distintos. Tais conceitos são essenciais para compreender o cinema e a arte como uma técnica social dos sentimentos e concernir que tanto a emoção como a moral podem ser consideradas formas de regulamentação do comportamento entre os sujeitos e que estão imersas em um caráter social.

\section{REFERÊNCIAS}

AGUIAR, W. M. J; OZELLA, S. Núcleos de Significação como Instrumento para a Apreensão da Constituição dos Sentidos. Psicologia, Ciência e Profissão, São Paulo, v. 26, n. 2, p. 224 231, 2006.

AGUIAR, W. M. J. de; OZELLA, S. Apreensão dos sentidos: aprimorando a proposta dos núcleos de significação. Rev. Bras. Estud. Pedagógicos, Brasília, v. 94, n. 236, p. 299322, Apr. 2013.

BARROCO, S. M. S.; SUPERTI, T. Vigotski e o estudo da psicologia da arte: contribuições para o desenvolvimento humano. Psicologia \& Sociedade, 26(1), 22-31, 2014.

BLANCK, G. Prefácio. In: VIGOTSKY, L. S. Psicologia Pedagógica: edição comentada. Trad. Cláudia Schilling. Porto Alegre: Artmed, 2003.

BOCK, A.; GONÇALVES, M. da G.; FURTADO, O. (Org.). Psicologia Sócio-Histórica: uma perspectiva crítica em psicologia. São Paulo: Cortez, 2009.

GATTI, B. A. Grupo focal na pesquisa em Ciências Sociais e Humanas. Brasília: Liber Livro Editora, 2012.

NUNES, A. B.; BRANCO, A. U. Desenvolvimento moral: novas perspectivas de análise. Psicol. Argum, Curitiba, v. 25, n. 51, p. 413-424, 2007.

RIBEIRO, M. A. G. Concepções e Funções da Arte na Arteterapia. 2002. Dissertação (Mestrado) - Curso de Psicologia, Departamento de Psicologia, Ucg - Universidade Católica de Goiás, Goiânia, 2002. Cap. 2

VÁZQUEZ, A. S. Ética. Rio de Janeiro: Civilização Brasileira, 2002.

TOASSA, G. Emoções e vivências em Vigotski. Campinas: Papirus, 2011.

TOASSA, G; SOUZA, M. P. R. de. As vivências: questões de tradução, sentidos e fontes epistemológicas no legado de Vigotski. Psicol. USP, São Paulo, v. 21, n. 4, p. 00, 2010.

VIGOTSKI, L. S. Arte como catarse. In: VIGOTSKI, L. S. Psicologia da arte. São Paulo: Martins Fontes, 1999.

VIGOTSKI, L. S. A formação social da mente: o desenvolvimento dos processos psicológicos superiores. 6. Ed. São Paulo: Martins Fontes, 1998.

VINHA, M. P.; WELCMAN, M. Quarta aula: a questão do meio na pedologia, Lev Semionovich Vigotski. Psicol. USP, São Paulo, v. 21, n. 4, p. 681-701, 2010. 
${ }^{\mathrm{i}}$ Acadêmica do curso de Psicologia (UEM). Ex-bolsista do Programa de Iniciação Científica - PIBIC/CNPQ/FA. Email: aomodeimelo@gmail.com

ii Doutor em Psicologia (UNESP/ASSIS). Professor Adjunto no Programa de Pós-Graduação em Psicologia e Departamento de Psicologia da Universidade Estadual de Maringá - UEM. Email: ampalves@uem.br 